\title{
CLINICAL AND CHEST X-RAY FEATURES OF PNEUMONIA IN INJECTING-DRUG USERS
}

\author{
Butova T. S. ${ }^{1}$, Butov D. O. ${ }^{2}$, Martynchyk O. S. ${ }^{1}$, Sinichenko O. S. ${ }^{1}$, Martymianova L. O. ${ }^{I}$ \\ ${ }^{1}$ V. N. Karazin Kharkiv National University, Kharkiv, Ukraine \\ ${ }^{2}$ Kharkiv National Medical University, Kharkiv, Ukraine
}

On an example of a clinical case in a patient with drug addiction, the reviewed clinical and chest X-ray features of community-acquired pneumonia, the diagnostic algorithms and the differential diagnostics are based on the recommendations of the Ukrainian Association of Pulmonology. The treatment strategy of the patient in the conditions of an ambulatory are described.

KEY WORDS: community-acquired pneumonia, injecting drug use, diagnosis, treatment strategy

\section{КЛІНІКО-РЕНТГЕНОЛОГІЧНІ ОСОБЛИВОСТІ ПНЕВМОНІї ПРИ ІН'СКЦЙНІЙ НАРКОМАНІї}

\author{
Бутова Т. С. ${ }^{1}$, Бутов Д. О. ${ }^{2}$, Мартинчик О. С. , Сініченко О. С. ${ }^{1}$, Мартим'янова Л. О. \\ ${ }^{1}$ Харківський національний університет імені В. Н. Каразіна, м. Харків, Україна \\ ${ }^{2}$ Харківський національний медичний університет, м. Харків, Україна
}

На прикладі клінічного випадку у пацієнта з наркозалежністю розглянуто клініко-рентгенологічні особливості негоспітальної пневмонії, алгоритми діагностики та диференційної діагностики, які засновані на рекомендаціях української асоціації пульмонологів. Описана тактика ведення пацієнта в умовах поліклініки.

КЛЮЧОВІ СЛОВА: негоспітальна пневмонія, ін'єкційна наркоманія, діагностика, тактика ведення

\section{КЛИНИКО-РЕНТГЕНОЛОГИЧЕСКИЕ ОСОБЕННОСТИ ПНЕВМОНИИ ПРИ ИНЪЕКЦИОННОЙ НАРКОМАНИИ}

\author{
Бутова Т. С. ${ }^{1}$, Бутов Д. А. ${ }^{2}$, Мартынчик А. С. ${ }^{1}$, Синиченко Е. ${ }^{1},{ }^{1}$ Мартимьянова Л. А. ${ }^{1}$ \\ ${ }^{1}$ Харьковский национальный университет имени В. Н. Каразина, г. Харьков, Украина \\ ${ }^{2}$ Харьковский национальный медицинский университет, г. Харьков, Украина
}

На примере клинического случая у пациента с наркозависимостью рассмотрено клиникорентгенологические особенности внебольничной пневмонии, алгоритмы диагностики и дифференциальной диагностики, которые основаны на рекомендациях украинской ассоциации пульмонологов. Описанная тактика ведения пациента в условиях поликлиники.

КЛЮЧЕВЫЕ СЛОВА: внебольничная пневмония, инъекционная наркомания, диагностика, тактика ведения

\section{INTRODUCTION}

According to statistical data, pneumonia ranks first among the causes of death from infectious diseases, the sixth among all causes of death and the fourth among causes of death in patients older than 65 years [1-2].

According to the National Report for 2017 on the Drug Situation in Ukraine in 2016, about three million people (about $14 \%$ of the population of Ukraine) are drug addicts [3].
Therefore, particular importance today is given to the problem of so-called «syringe» infections, among which the most frequent infections are HIV, viral hepatitis B and C, bacterial hematogenous infections that cause serious complications: pneumonia, septicemia, bacterial endocarditis [3].

With intravenous drug addiction, after nonsterile and usually unsuccessful attempts to gain access to peripheral veins, proximal and central veins are used to inject the drug, which leads to 
a rapid spread and deeper penetration of bacterial agents into the human body [4].

In persons who use drugs intravenously, most often an infection is caused by Golden Staph (Staphylococcus aureus) [5]. This can be explained by the fact that $25-40 \%$ of the population is permanent carriers of this bacterium, which is stored on the skin [5] and with intravenous interventions (procedures) the bacteria enters the systemic circulation.

Thus, drug users, even without immunedeficiency, experience pneumonia of staphylococcal etiology, which is characterized by resistance to antibiotic therapy, severe course, rapid progression, frequent complications and high lethality [6-7].

\section{MATERIALS AND METHODS}

In the Kharkiv city ambulatory No. 24 a therapist examined a 37-year-old man. The doctor interviewed the patient, collected anamnesis of the disease and life (medical history), objectively examined the patient then he immediately conducted a clinical and laboratory (clinical analysis of blood, urine) and instrumental (chest X-ray) examination. The diagnosis and healthcare strategy were based on the recommendations of decree No. 128 of the Ministry of Health of Ukraine dated March 19, 2007 «On the approval of clinical protocols for the provision of medical care in the «Pulmonology» specialty» [8].

\section{OBJECTIVES}

To consider on an example of a clinical case the diagnostic features and tactics of management of a patient with pneumonia with a background of drug-injecting addiction in conditions of an ambulatory.

\section{RESULTS AND DISCUSSION}

A man 37 years, old was admitted to the Kharkiv city ambulatory No. 24 with complaints of a persistent wet cough of yellowgreen viscous sputum, dyspnea at rest (shortness of breath), pain in the lower right part of the chest, worse with inspiration, increased sweating combined with chills, general weakness. He was ill for 10 days, when after hypothermia, a dry cough appeared, the body temperature increased to $37.80^{\circ} \mathrm{C}$. $\mathrm{He}$ started self-treated, he took paracetamol $500 \mathrm{mg}$ 3 times a day, 1 glass of herbal infusion «No. 2» glass 2-3 times a day. The last 3 days he took amoxicillin $500 \mathrm{mg} 3$ times a day. The state of his health worsened so he came to the therapist. From the anamnesis of life - has been injecting drugs for about 5 years. Objectively: severe bad health condition, temperature of the body $-40^{\circ} \mathrm{C}$, paleness and increased moisture of the skin. Percutally dull pulmonary sound below the 5 intercostal spaces to the right of the paravertebral to the middle axillary line and below the 4 intercostal spaces from the middle axillary line to the right parasternal line, where auscultatory breathing was not determined. Over the remaining areas of the lungs a rigid breathing with prolonged exhalation and single small «bubbly» wheeze heard. The respiratory rate is $30 / \mathrm{min}$., auscultation of the heart- deaf tones were determined. Heart rate -110 beats per minute. Blood pressure $-90 / 65 \mathrm{~mm} \mathrm{Hg}$.

Recommended examination according to the following plan: a clinical blood test, a clinical urine analysis, a biochemical blood test (CRP, total protein and its fractions), a blood test for HIV, a clinical sputum analysis + the presence of mycobacterium tuberculosis, a bacterial sputum culture + detection of sensitivity to antibiotics, chest x-ray, spirography.

In the conditions of the ambulatory. The results of the medical examination were obtained: in the blood count test - leukocytosis $(16.7 \mathrm{~g} / \mathrm{l})$, accelerated ESR $(29 \mathrm{~mm} / \mathrm{h})$. On chest radiography: in both of the lung cavities all over there are multiple cavity formations of various sizes in diameter (from 0.5 to $3 \mathrm{~cm}$ ) with the presence of insignificant liquid levels. On the right at the level of 4-12 ribs and in the sinus is a shading of medium intensity, a homogeneous structure with an oblique fuzzy contour. Conclusion: bilateral abscessed pneumonia complicated by pleurisy to the right. Multiple abscesses of the lungs (Fig. 1). 

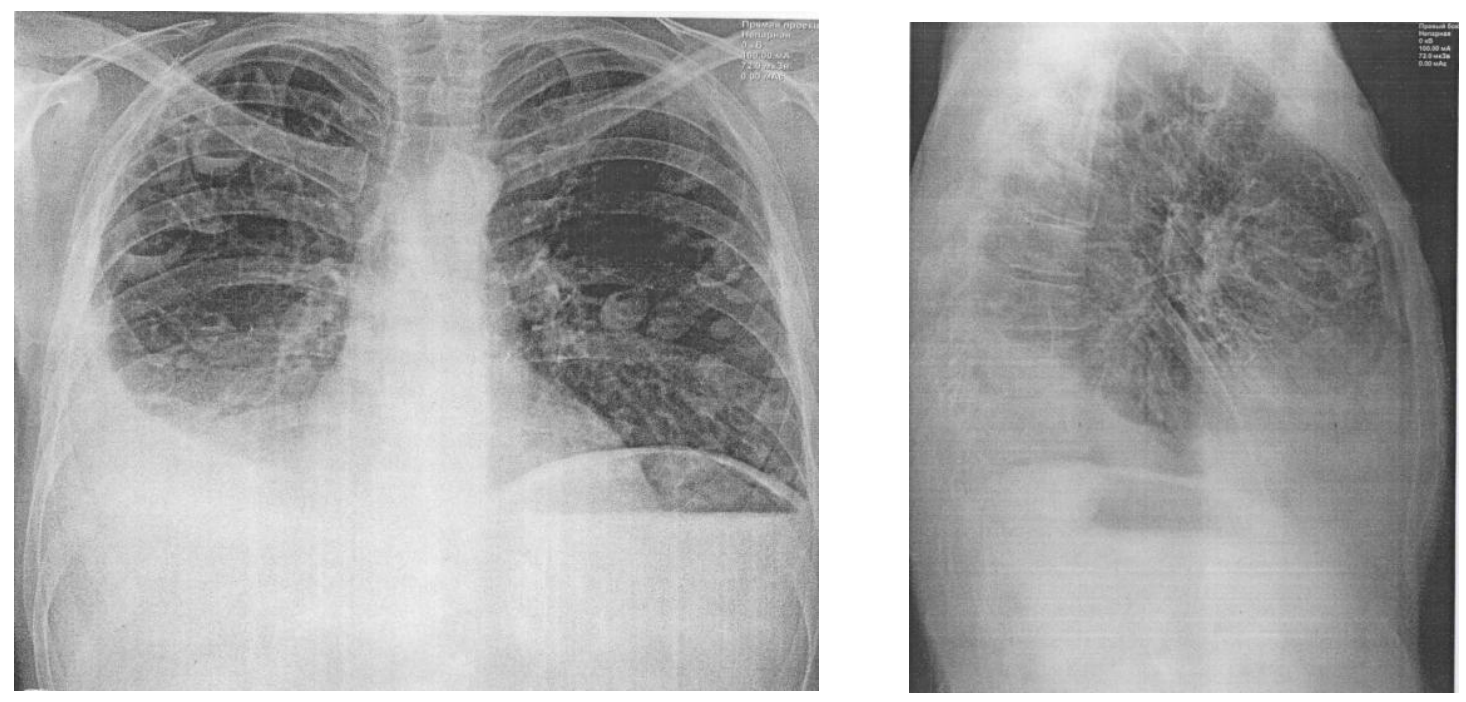

Fig. 1 Chest X-ray in the frontal and lateral projections

The main diagnosis: acquired bilateral abscessing pneumonia, IV clinical group. Multiple abscesses of the lungs. Pulmonary insufficiency III degree.

Complications: right-sided exudative pleurisy.

Concomitant diagnosis: injecting-drug addiction.

Since the patient came to the doctor after self-treatment, it was necessary to evaluate its effectiveness. The determination of the ineffectiveness of antibiotic therapy is carried out 48-72 hours after the start of the drug and is based on the following criteria:

- Preservation or intensification of fever, clinical symptoms, intoxication (Our patient has it);

- Appearance or persistence of hemodynamic instability (Our patient has it);

- Development or enhancement of respiratory failure (Our patient has it);

- There is a need for artificial ventilation (Our patient does not require it);

- Negative chest X-ray picture of the chest (Our patient has it).

In accordance with the algorithm for assessing the effectiveness of antibiotic therapy: the use of amoxicillin (500 mg 3 times a day) in our patient was ineffective.

Since the spectrum of microbial flora in patients of the IV clinical group is diverse (Legionella spp., H. Influenza, Gram-negative enterobacteria, S. Aureus, S. Pneumoniae, M. Pneumonia, in the presence of modifying factors, the pathogen of pneumonia may be P. aeruginosa), it is necessary to consider the features the course of pneumonia, depending on specific pathogens [6]:

- Legionellosis pneumonia, as a rule, occurs in persons visiting rooms with air conditioners, swimming pools and showers. It's characterized by severe course (tendency), diarrhea, neurological symptoms, hepatic dysfunction;

- A pneumonia which is caused hemophilia often occurs in people suffering from chronic bronchopulmonary diseases and alcoholism, is characterized by severe course, discharge of thick sputum with blood, large infiltrates, the probability of getting abscess;

- Staphylococcal pneumonia has an acute onset, severe course (tendency), limited infiltrates (pocket), frequent abscesses and resistance to a group of penicillin's;

- Pneumococcal pneumonia is characterized by acute onset, severe course (tendency), severe fever, prevalence of infiltrates and good response to penicillin antibiotics;

- Mycoplasma pneumonia develops in young patients, it has an acute onset, mild to moderate-course (tendency), catarrhal inflammation of the upper respiratory tract (runny nose, sore throat), cough with scant sputum.

Thus, we can assume that our patient develops staphylococcal pneumonia. 
The choice of patient treatment location is determined depending on the evaluation of the severity of pneumonia according to certain criteria.

The «small» criteria include:

- Respiratory rate $\geq 30$ in $1 \mathrm{~min}$. (Our patient has it),

- impaired consciousness (Our patient does not have it),

- $\mathrm{SaO} 2<90 \%$ (Not determined in our patient),

- The partial pressure of oxygen in the arterial blood $(\mathrm{PaO} 2)$ is below $60 \mathrm{~mm} \mathrm{Hg}$. (Not determined in our patient).

- $\quad$ Systolic blood pressure $<90 \mathrm{~mm} \mathrm{Hg}$ (Our patient has it)

- Bilateral or multiple lung damage, cavity decay, pleural effusions (Our patient has it).

To «large» criteria of a heavy current of pneumonia carry:

- The need for artificial ventilation (Our patient does not need it),

- Rapid progress of focal-infiltrative changes in the lungs (increase in infiltration rates by more than $50 \%$ within the next 2 days) (Our patient does not have it),

- Septic shock or the need for vasopressor $\geq 4 \mathrm{~g}$ (our patient does not have it),

- Acute renal failure of the lungs (Our patient does not have it).

The severe course of pneumonia which matches to $\geq 2$ articles from the «small» criteria or 1 article from the «large» criteria, requires the urgent hospitalization of patients in the intensive care unit (ICU). Our patient has a severe course of acquired pneumonia ( 3 small criteria), so he must be urgently hospitalized in the ICU.

To summarize: the acute onset, severe course, the presence of limited infiltrates and abscesses on the chest $\mathrm{x}$-ray, resistance to the penicillin group hypothetically correspond to the staphylococcal etiology of pneumonia, which is confirmed in the spectrum of microflora in the patients of the IV clinical group, where one of the possible causative agents is S. aureus. The patient has three articles from «small» criteria for the severe course of pneumonia, respiratory rate $\geq 30$ in $1 \mathrm{~min}$., Systolic blood pressure $<90 \mathrm{~mm} \mathrm{Hg}$, multiple lung damage with decay cavities and hydrothorax, which was an indication for hospitalization in the intensive care unit and intensive care. Also, the presence of fluid in the pleural cavity requires the use of instrumental methods of diagnosis and treatment in conditions of the thoracic surgery department.

Based on the above, the patient was urgently hospitalized in the intensive care unit of the Department of Thoracic Surgery with the help of an ambulance brigade.

\section{CONCLUSIONS}

1. Community-Acquired pneumonia acquired by intravenous drug use is characterized by a severe course, febrile body temperature, severe specific lung disease.

2. On the example of this clinical case, the importance of express diagnostics of pneumonia at the ambulatory stage was confirmed to determine the correct tactics of patient management.

\section{REFERENCES}

1. WHO. URL: http://www.who.int/mediacentre/factsheets/fs310/en/index.html (Last accessed: 17.03.2018).

2. Linnik M. I., Nedospasova O. P., Tarasenko O. R., Kapustyak V. I., Bushura I. B., Nikiforova L. G. Comparative data on the prevalence of respiratory diseases and medical care for patients with pulmonologic and allergic diseases in Ukraine for 2010-2016. Kiev: Lira-K, 2017. 48p.

3. National report for 2017 on the narcotic situation in Ukraine (according to 2016). URL: http://www.ummcda.org.ua/index.php/86-natsionalnij-zvit-za-2017-rik-shchodo-narkotichnoji-situatsiji-vukrajini-za-danimi-2016- hand (Last accessed: 17.03.2018).

4. Holbaev S. A. Features of the course and treatment of postinjectional gonya-inflammatory and vascular complications in patients suffering from drug addiction: The dissertation for a scientific degree candidate of medical sciences: K737.005.03 / Tajik State Medical University. Dushanbe, 2012. 100p. 
5. Tong S. Y., Davis J. S., Eichenberger E., Netherlands T. L., Fowler V. G. Staphylococcus aureus infections: epidemiology, pathophysiology, clinical manifestations, and management. Clinical Microbiology Reviews, 2015. No. 28 (3). P. 603-661.

6. Feshchenko Yu. I., Golubovskaya O. A., Goncharov K. A. and others. Unresponsive pneumonia in adults: etiology, pathogenesis, classification, diagnostics, antibiotic therapy. Ukrainian pulmonology journal. 2012. No. 4. P. 5-17.

7. Landyshev Yu. S., Goborov N. D., Tsukanova G. D. Infectious complications in chronic dezororfine drug addiction. Amur Medical Journal. 2017. No. 1 (17). P. 76-81.

8. Order of the Ministry of Health of Ukraine No. 128 dated 19.03.2007. On approval of Clinical Protocols for the Provision of Medical Aid in the Specialty «Pulmonology». 21 p. 